\title{
Comparison of in vitro-cultured and wild-type Perkinsus marinus. II. Dosing methods and host response
}

\author{
Marnita M. Chintala ${ }^{1, *}$, David Bushek ${ }^{2}$, Susan E. Ford ${ }^{3}$ \\ ${ }^{1}$ United States Environmental Protection Agency (US EPA), Office of Research and Development (ORD), National Health and \\ Environmental Effects Laboratory (NHEERL), Atlantic Ecology Division, 27 Tarzwell Drive, Narragansett, Rhode Island \\ 02882, USA \\ ${ }^{2}$ Baruch Marine Field Laboratory, Belle W. Baruch Institute for Marine Biology and Coastal Research, \\ University of South Carolina, PO Box 1630, Georgetown, South Carolina 29442, USA \\ ${ }^{3}$ Haskin Shellfish Research Laboratory, Institute of Marine and Coastal Sciences, Rutgers University, 6959 Miller Avenue, \\ Port Norris, New Jersey 08349, USA
}

\begin{abstract}
Endoparasites must breach host barriers to establish infection and then must survive host internal defenses to cause disease. Such barriers may frustrate attempts to experimentally transmit parasites by 'natural' methods. In addition, the host's condition may affect a study's outcome. The experiments reported here examined the effect of dosing method and host metabolic condition on measures of virulence for the oyster parasite Perkinsus marinus. Oysters, Crassostrea virginica, were challenged with wild-type and cultured forms of $P$. marinus via feeding, shell-cavity injection, gut intubation and adductor-muscle injection. For both parasite types, adductor-muscle injections produced the heaviest infections followed by shell-cavity injection, gut intubation, and feeding. There was no difference in parasite burdens between oysters fed cultured cells by acute vs chronic dosing, and parasite loads stabilized over time, suggesting a dynamic equilibrium between invasion and elimination. P. marinus distribution among tissues of challenged oysters indicated that parasites invaded the mantle and gill, as well as the gut, which has been considered the primary portal of entry. Frequency distributions of $P$. marinus in oysters challenged with 3 different culture phases indicated an aggregated distribution among hosts and suggested that stationary-phase parasites were easiest for the oyster to control or eliminate and log-phase parasites were the most difficult. Host metabolic condition also affected experimental outcomes, as indicated by increased infection levels in oysters undergoing spawning and/or exposed to low oxygen stress.
\end{abstract}

KEY WORDS: Disease $\cdot$ Parasite $\cdot$ Oyster $\cdot$ Crassostrea virginica $\cdot$ Portal of entry $\cdot$ Metabolic condition Resale or republication not permitted without written consent of the publisher

\section{INTRODUCTION}

Endoparasites must breach physical, chemical, and behavioral barriers of their intended host to establish an infection, and then must survive host internal defenses to reproduce and cause disease. A parasite's ability to cause disease is termed 'pathogenicity' and the term 'virulence' is a measure of its relative patho-

*E-mail: chintala.marty@epamail.epa.gov genicity (Tanada \& Fuxa 1987, Osterhout 1999). Although virulence is an inherent quality of a pathogen, modifications in the immediate environment of a parasite (either inside or outside the host) may change its ability to infect and establish itself in a host, altering its apparent or measured virulence. A change in the effectiveness of any host defense (a barrier to infection) may alter a parasite's apparent virulence, even though its inherent virulence is not changed. For marine molluscs, barriers to infection and disease development include shell and pallial curtain closure, 
filtering activity, sorting and rejecting of particles by gills and palps, the epithelium and its mucus coating, digestive enzymes, and the internal defense system.

Barriers to infection are effective not only in nature, but also in experimental settings where they may frustrate attempts to transmit parasites by 'natural' methods. For instance, both Mackin et al. (1953) and Chu (1996) reported difficulty in establishing infections via feeding of the parasite Perkinsus marinus to eastern oysters, Crassostrea virginica. Most challenge experiments with $P$. marinus utilize shell-cavity injection, although its efficacy in relation to other methods has not been thoroughly evaluated (Chu 1996). In a preliminary comparison of dosing methods, Bushek et al. (1997) exposed C. virginica to in vitro-cultured P. marinus in doses ranging from 0 to $10^{7}$ parasites per oyster via 3 routes: feeding, shell-cavity injection, and injection directly into the hemolymph sinuses of the adductor muscle. After $2 \mathrm{mo}$, no infections were detected in fed oysters, moderate infections were found after shellcavity injection, and heavier infections occurred after adductor-muscle injection. In another experiment, oysters were examined just $4 \mathrm{~d}$ after dosing by the same methods and were found to have a similar dosing method-response pattern (Bushek et al. 1997). Obviously, infection development was more rapid when parasites were injected directly into the circulatory system compared to when they were mixed with food; however, this dosing method is hardly an approximation of natural conditions. A comparison between parasite burdens resulting from shell-cavity and intramuscular injections showed no statistically significant differences in either experiment even though infections following intramuscular injection developed more rapidly. Thus, shell-cavity injection, which is less invasive and somewhat closer to the natural situation in that it does not circumvent sorting, digestive, or epithelial barriers, may be nearly as effective in inducing infections as the highly artificial direct inoculation into the circulatory system.
In addition to dosing method, host physiological state is likely to influence the outcome of the hostparasite interaction (Newell \& Barber 1988, Fisher et al. 1996b). Oysters undergo major seasonal metabolic changes, many of them linked to the reproductive cycle. Post-spawning bivalves are considered to be in a weak physiological state and perhaps more susceptible to parasitism than at other times. Ford et al. (2002, this issue) reported a possible link between spawning and elevated Perkinsus marinus infection levels after laboratory challenge. Mackin (1962), however, found no relationship between the post-spawning state of Crassostrea virginica and $P$. marinus infections in a natural setting. Further, there are clear seasonal as well as site-specific differences in numbers, activity, and types of circulating hemocytes in oysters (Fisher et al. 1989, 1996a, Oliver \& Fisher 1995) that may affect response to challenge by experimentally delivered parasites. With the advent of continuous in vitro culture of P. marinus (Gauthier \& Vasta 1993, Kleinschuster \& Swink 1993, La Peyre et al. 1993), challenge studies can be done at any time of the year. Consequently, investigators are likely to use oysters that vary considerably in their metabolic condition from one experiment to another and this variability could significantly affect the outcome of challenge experiments.

The experiments reported here were undertaken to test the hypotheses that dosing method and oyster metabolic condition can affect the measured or apparent virulence of Perkinsus marinus, as indicated by in vivo parasite proliferation in oyster tissues and subsequent oyster mortality. We hypothesized that the relative effectiveness of the different methods would be adductor muscle $>$ intubation $>$ shell cavity $>$ feeding (Table 1). Post-challenge tissue distribution of P. marinus was used to examine the role of infection barriers. The study was also intended to facilitate inter-laboratory standardization and comparisons of $P$. marinus exposure studies, especially those using in vitrocultured parasites.

Table 1. Presumed barriers to infection of oysters by water-borne parasites, indicating the barriers hypothesized to be in place with various dosing methods

\begin{tabular}{|lcccc|}
\hline Dosing method & \multicolumn{3}{c|}{ Barriers } \\
\hline Feeding & $\begin{array}{c}\text { Shell } \\
\text { Pallial curtain } \\
\text { Filtering behavior }\end{array}$ & Sorting by gill and palps & $\begin{array}{c}\text { Epithelium } \\
\text { Digestion }\end{array}$ & Internal defense system \\
Shell-cavity injection & & Sorting by gill and palps & Epithelium & Internal defense system \\
Stomach intubation & & & Digestion & Internal defense system \\
& & & Epithelium & Digestion \\
Adductor sinus injection & & & & Internal defense system \\
\hline
\end{tabular}




\section{MATERIALS AND METHODS}

Oysters. Hatchery-reared Crassostrea virginica, highly susceptible to Perkinsus marinus, were obtained from Mook SeaFarms in Damariscotta, Maine, USA. All groups were produced and reared under similar conditions and, within each batch, all oysters were of the same age. They were shipped overnight to the Haskin Shellfish Research Laboratory, where they were maintained in the laboratory at $10^{\circ} \mathrm{C}$ and $25 \mathrm{ppt}$ in $1 \mu \mathrm{m}$-filtered sea water (FSW) before the start of each experiment (Table 2). Maintenance at $10^{\circ} \mathrm{C}$ was intended to reduce metabolic activity while oysters were being held for varying periods before challenge experiments. Ten oysters were sacrificed initially and assayed to determine whether they were free of $P$. marinus (see subsection 'Sample processing' below). Before and during each experiment, oysters were fed a daily maintenance diet of approximately $2 \times 10^{6}$ cells oyster $^{-1}$ of a 2:1 mixture of Isochrysis spp. and Chaetoceros spp. All experiments were conducted in FSW at 26 to $28^{\circ} \mathrm{C}$ and $25 \mathrm{ppt}$. Water was aerated and changed weekly. Wastewater was treated with household bleach (minimum $10 \mathrm{ppm}$ residual $\mathrm{Cl}_{2}$ ) for at least $24 \mathrm{~h}$ prior to disposal. All experiments were terminated after 84 d, except Expt III, which ended on Day 87.

Expt I. Dosing methods. The effect of different dosing procedures on infectivity and disease development was measured using both wild-type and cultured Perkinsus marinus. Parasites were obtained from in vitro Culture ATCC 50509 (= DBNJ-1 of Bushek \& Allen 1996) or isolated from naturally infected oysters (see Ford et al. 2002 for details) and delivered by 1 of 4 methods: feeding, shell-cavity injection, intubation, or adductor-muscle injection. Each oyster was first numbered, then weighed in air and under water. The difference, considered an estimate of wet tissue weight (Andrews 1961), was used to weight-standardize the dose administered to each individual. All oysters, regardless of parasite type or method of delivery, were given a single dose of $10^{6} \log$-phase $P$. marinus per gram wet tissue $\left(\mathrm{g}^{-1} \mathrm{wwt}\right)$. Twenty oysters were dosed by each of the 4 methods, 10 with wild-type parasites and 10 with cultured parasites. Stock parasite concentrations were determined by hemocytometer and adjusted to provide delivery volumes of 25 to $50 \mu \mathrm{l}$. An additional 10 control oysters were not exposed to any $P$. marinus. Parasite delivery methods were as follows:

Feeding: While in their individual containers, oysters were fed their algal diet spiked with $P$. marinus on Day 0 . The oysters were not given food for $24 \mathrm{~h}$ prior to the start of the experiment to ensure that they would feed once the spiked diet was added.

Shell-cavity injection: The shell edge of each oyster was notched adjacent to the gills to open a small hole, just large enough to insert a needle. A $1 \mathrm{ml}$ tuberculin syringe with a 25 -gauge blunt-tip needle, was used to inject the Perkinsus marinus into the shell cavity. Each oyster was then held shut overnight, with a wide rubber band covering the notch to prevent the oyster from ejecting the inoculum. The oysters were covered with a damp cloth, kept out of water overnight at $10^{\circ} \mathrm{C}$, and then returned to their individual containers after the rubber bands had been removed.

Intubation: Oysters were intubated following a modification of the Alvarez et al. (1992) procedure. A rectangular portion of the left valve from just above the adductor muscle to the umbo was carefully cut with a Dremel $^{\circledR}$ cutting disk and removed. Perkinsus marinus were then introduced between the labial palps into the oyster's mouth using a $1 \mathrm{ml}$ tuberculin syringe with a large-bore needle, the point of which had been cut off and the tip sanded smooth. Rolled Parafilm ${ }^{\circledR}$ was placed around the edge of the shell opening, and the piece of shell was returned to the oyster and sealed with Trim Dental Plastic (H. J. Co.). The oysters were then placed under an ultraviolet light overnight to harden the dental plastic.

Adductor sinus injection: The shell edge of each oyster was notched adjacent to the adductor muscle to open a small hole, just large enough to insert a needle. Parasites were delivered into the adductor muscle

Table 2. Crassostrea virginica. Shipment and initial sampling dates, and initial measurements of Maine oysters used in experiments. Values are means (SEM); \#P. m. g ${ }^{-1}$ wwt: no. of Perkinsus marinus $\mathrm{g}^{-1}$ oyster wet $\mathrm{wt}_{\text {; }} \# \geq P . \mathrm{m} . \mathrm{g}^{-1} \mathrm{wwt} / \#$ samp.: ratio no. of oysters with 1 or more P. marinus $\mathrm{g}^{-1}$ wet wt to no. of oysters sampled. Parasites could have been acquired at the Haskin Laboratory between arrival and sampling dates;

\begin{tabular}{|lcccccccc|}
\hline Expt & $\begin{array}{c}\text { Arrival } \\
\text { date } \\
(\mathrm{m} / \mathrm{d} / \mathrm{yr})\end{array}$ & $\begin{array}{c}\text { Sampling } \\
\text { date } \\
(\mathrm{m} / \mathrm{d} / \mathrm{yr})\end{array}$ & $\begin{array}{c}\# P . m . \\
\mathrm{g}^{-1} \mathrm{wwt}\end{array}$ & $\begin{array}{c}\# \geq 1 P . \mathrm{m} . \\
\mathrm{g}^{-1} \mathrm{wwt} / \\
\# \mathrm{samp} .\end{array}$ & $\begin{array}{c}\text { Shell } \\
\text { height } \\
(\mathrm{mm})\end{array}$ & $\begin{array}{c}\text { Total } \\
\text { wt } \\
(\mathrm{g})\end{array}$ & $\begin{array}{c}\text { Estimated } \\
\text { tissue wt } \\
(\mathrm{g})\end{array}$ & $\begin{array}{c}\text { Pre-expt } \\
\text { holding time } \\
(\mathrm{d})\end{array}$ \\
\hline I & $9 / 9 / 94$ & $9 / 20 / 94$ & $0.76(0.34)$ & $1 / 10$ & $53(0.6)$ & $13.0(0.39)$ & $7.8(0.23)$ & 10 \\
III & $1 / 10 / 94$ & $1 / 25 / 94$ & $0.98(0.74)$ & $1 / 10$ & $75(0.6)$ & $64.5(0.91)$ & $17.1(0.27)$ & 60 \\
II & $6 / 14 / 95$ & $6 / 27 / 95$ & $0.03(0.01)$ & $0 / 10$ & $72(0.5)$ & $60.3(1.07)$ & $16.1(0.28)$ & 24 \\
IV & $6 / 28 / 95$ & $6 / 29 / 95$ & $0.31(0.12)$ & $1 / 10$ & $84.2(8.1)$ & $81.1(16.6)$ & $21.6(4.4)$ & $14 \& 42$ \\
\hline
\end{tabular}


hemolymph sinuses using a 1-mL tuberculin syringe with a 26-gauge needle. These oysters were returned immediately to their individual containers after injection.

After the dosing procedures, each oyster was placed in a 1.51 covered container with 11 aerated FSW. The delivery time for each method was adjusted so that all oysters were returned to the water at the same time.

Virulence index. The ability of Perkinsus marinus to infect after delivery by the various dosing methods was assessed using survival time and parasite burdens in survivors at the end of the experiment. Because some methods produced high mortality and others produced none, there was a disparity across treatments in the number of oysters in each category, which made comparisons difficult. We therefore combined the 2 measures into a single 'virulence index' (VI). Each oyster was assigned a number from 0 to 5 according to when it died during the experiment (Table 3). Oysters that survived until the end of the experiment were scored 0 , as were those that died during the first week (which we considered to have died from trauma). Similarly, each oyster (live or dead) was assigned a number from 0 to 5 according to its parasite load (Table 3). Oysters with fewer than 10 parasites $\mathrm{g}^{-1}$ wwt were scored 0 , as this body burden was typical of controls. The 2 scores for each oyster were summed and an average calculated for each treatment.

Expt II. Acute vs chronic feeding of parasites and their subsequent distribution in oyster tissues. The effect of providing a dose of parasites once or as an equal amount split among smaller doses given over a prolonged period was investigated using cultured parasites (see Ford et al. 2002 for culture details) delivered via feeding. The total dose of $2.4 \times 10^{8}$ parasites was chosen to simulate the cumulative dosage an oyster might encounter in 2 mo in an enzootic area (Dungan $\&$ Roberson 1993). Cultured parasites were harvested in the log phase of growth from Isolate LX-4 (Ford et al.

Table 3. Crassostrea virginica. Calculation of virulence index. Each individual was rated according to survival time and infection intensity of Perkinsus marinus. The 2 scores were summed to provide a composite measure of virulence

\begin{tabular}{|lcrc|}
\hline \multicolumn{2}{|c|}{$\begin{array}{c}\text { Survival time } \\
\text { Day to } \\
\text { death }\end{array}$} & Rating & \multicolumn{2}{c|}{ Infection intensity } \\
$\log _{10}$ P. marinus & Rating \\
\hline Survivor & 0 & $0-0.999$ & 0 \\
$72-84$ & 1 & $1.000-2.349$ & 1 \\
$56-71$ & 2 & $2.350-3.699$ & 2 \\
$40-55$ & 3 & $3.700-5.049$ & 3 \\
$24-39$ & 4 & $5.050-6.399$ & 4 \\
$8-23$ & 5 & $6.400-7.750$ & 5 \\
$1-7$ & 0 & & \\
\hline
\end{tabular}

2002). They were transferred 20 times (Passage 3 to Passage 23) during the experiment.

Thirty-six oysters were assigned to each of 2 Perkinsus marinus feeding treatments; 18 oysters were used as unchallenged controls. Oysters were placed in separate, individually aerated, 1.51 containers with 11 FSW at the start of the trial. Oysters in the first treatment group (acute exposure) each received a single dose of $2.4 \times 10^{8} P$. marinus mixed with their food at the start of the experiment. Each oyster in the second group (chronic exposure) received 24 equal doses of $10^{7} P$. marinus parasites mixed with food for the first 8 wk of the experiment $\left(3 \mathrm{wk}^{-1}\right)$.

Live oysters were sampled on Days 3, 7, 14, 28, 56 and 84 post-challenge to determine the time-course of infection development under the 2 dosing regimes. Oysters were assigned to sampling dates by lottery before the start of the experiment. At each date, 6 oysters from each treatment group and 3 controls were sampled. Each oyster was exsanguinated from the adductor muscle sinus using a syringe and needle inserted through a notch in the shell. The oyster was then shucked, and the soft tissue weighed and dissected into mantle, gill, digestive gland and remaining viscera (mostly gonad, adductor muscle, heart, and kidney). Dissected tissues were individually weighed and processed as described below (subsection 'Sample processing'). Parasite counts were obtained for individual tissues and summed to represent the total parasite burden of each oyster. Dead oysters collected during the experiment were processed for total body burden only.

Expt III. Parasite distribution in oyster tissues after shell-cavity injection. Different culture phases of Perkinsus marinus (lag, log or stationary) were injected into the shell cavities of oysters as part of an experiment reported elsewhere (Ford et al. 2002) and sampled on Days 3 and 87 post-inoculation to compare initial and final parasite distributions within tissues. The notches used for inoculation were reopened and the fluid within the shell cavity was removed with a needle and syringe. The oyster was exsanguinated using a second syringe and needle inserted through the same notch into the adductor muscle sinus. Shell-cavity fluid and hemolymph volumes were recorded. The oyster was then shucked, and dissected into the digestive gland and remaining soft tissues, which were individually weighed. The 4 compartments (shell cavity fluid, hemolymph, digestive gland and remaining tissues) were processed as described below (subsection 'Sample processing'). Parasite counts were obtained for individual tissues and fluids, and these were summed to obtain a total for each oyster.

Expt IV. Metabolic condition of host. Results of a challenge experiment reported elsewhere (Ford et al. 2002) suggested that the condition of experimental 
oysters, including changes occurring during acclimation, might influence the results of a dosing trial. To investigate the possibility that the length of this period could affect the outcome of an infection experiment, we compared mortality and parasite burdens in oysters held for 2 and 6 wk before challenge. Upon arrival at the laboratory, 48 oysters were assigned to each of the 2 pre-challenge holding periods. The first group was held in 2001 barrels in FSW at $10^{\circ} \mathrm{C}$ and $25 \mathrm{ppt}$ for $2 \mathrm{wk}$ prior to challenge with Perkinsus marinus. The second group was held under the same conditions for $6 \mathrm{wk}$ prior to challenge. These particular holding times and conditions were associated with different results in the previous experiment. At the designated time, each oyster received 2 injections into the shell cavity, $1 \mathrm{wk}$ apart, of $10^{6}$ parasites $\mathrm{g}^{-1}$ wwt of the LX-4 culture (see Ford et al. 2002 for culture details). The oysters were then placed into $15 \mathrm{l}$ buckets with 12 oysters per bucket, 4 buckets per treatment. Five oysters, not exposed to $P$. marinus, were placed in a separate bucket at the start of the $2 \mathrm{wk}$ treatment, and remained as controls for the 6 wk treatment.

Sample processing. Dead oysters were removed daily, recorded, measured, weighed and assayed for parasite burden. At the end of each experiment, all surviving oysters were measured, shucked, and the tissues weighed. Total body or individual-tissue parasite burdens were estimated according to the methods of Bushek et al. (1994) as modified by Fisher \& Oliver (1996). In this assay, the entire soft tissue mass, or dissected tissues, of each oyster is minced and incubated in fluid thioglycollate medium, which causes the parasite to enlarge (Ray 1952). The enlarged 'hypnospore' phases are freed from oyster tissues with $\mathrm{NaOH}$, washed, and concentrated (Choi et al. 1989). Three to four $100 \mu \mathrm{l}$ subsamples of the resulting parasite suspension are dispersed onto filter paper and counted. If subsample counts are $<20$, the entire suspension is counted. Counts are expressed as parasites $\mathrm{g}^{-1}$ wwt or $\mathrm{ml}^{-1}$ or as parasites whole oyster ${ }^{-1}$.

Statistics. Comparison of mortality among treatments within each experiment was made using nonparametric survival analysis (Mantel-Cox logrank test, Abacus Concepts 1994). Parasite densities were transformed $\left(\log _{10}[x+1]\right)$ before being subjected to analysis of variance (ANOVA) using a general linear model (SAS Institute 1990). The virulence indices were also analyzed by ANOVA. When oysters were held in buckets, the buckets were nested within the treatment factor of the ANOVA. The Bonferroni post-hoc test was used for pairwise comparisons. Tissue weights were similarly analyzed to determine whether differences in weight-specific parasite burdens were independent of changes in soft tissue weight. Differences between means were considered significant at $\alpha=0.05$.
Controls were not included in the models because the hypotheses we were testing were between treatment types, not between treatments and controls.

\section{RESULTS}

\section{Expt I. Dosing methods}

Mortality

Challenge with wild-type Perkinsus marinus consistently produced more and earlier mortality than did challenge with cultured parasites regardless of parasite delivery technique (Fig. 1, see also Ford et al. 2002). There was also a distinct effect of dosing method in those groups given wild-type parasites ( $p=$ 0.006). When challenged with wild-type $P$. marinus, half the oysters inoculated via the adductor muscle, $30 \%$ of those intubated, and $10 \%$ of those injected via the shell cavity died within the first 2 wk after challenge (Fig. 1A). After this initial mortality, few deaths occurred until Week 7, when a second phase of mortality began which lasted through Week 11. At the con-

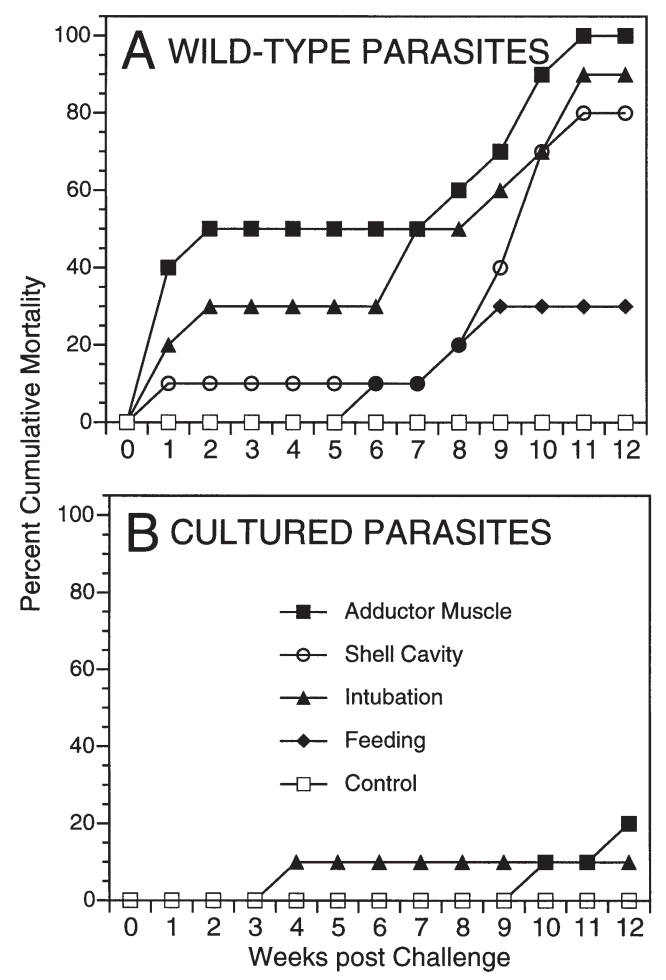

Fig. 1. Crassostrea virginica. Cumulative mortality of susceptible eastern oysters challenged with $10^{6}$ parasites ${ }^{-1}$ wwt of wild-type and in vitro-cultured Perkinsus marinus using 4 different dosing methods. Starting $\mathrm{N}=10$ for each experimental group and 5 for controls 
clusion of the experiment, total mortality in oysters dosed with wild-type parasites was 30\% in the group fed $P$. marinus and 80 to $100 \%$ in the other dosing treatments. In contrast, only 3 of 40 oysters dosed with cultured $P$. marinus parasites died: one that had been intubated died in Week 4, and 2 that had been inoculated into the adductor muscle died in Weeks 10 and 12 (Fig. 1B). No control oysters died.

\section{Parasite burdens}

Perkinsus marinus was detected in all live and dead oysters. Mean parasite burdens in oysters surviving to
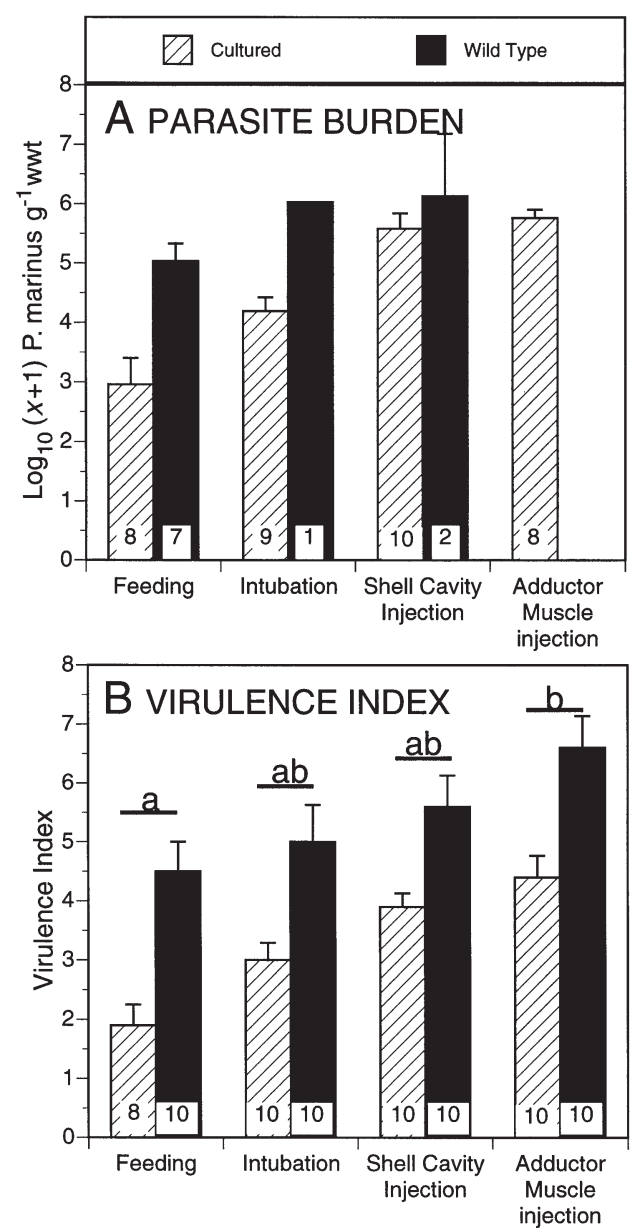

Fig. 2. Perkinsus marinus. (A) Mean $( \pm \mathrm{SEM})$ parasite densities in tissues of susceptible eastern oysters, Crassostrea virginica, surviving $84 \mathrm{~d}$ after challenge with $10^{6}$ wild-type or cultured parasites $\mathrm{g}^{-1}$ wwt via different dosing methods. (B) Mean $( \pm$ SEM) virulence index (see text for explanation) of wild-type and in vitro-cultured $P$. marinus delivered by different dosing methods. The number of oysters in each group is shown at bottom of bars. Letters above the bars in (B) represent Bonferroni mean separation differences (wild-type and cultured parasites combined for each dosing method). Means with the same letter are not significantly different the end of the experiment were between $10^{4}$ and $10^{6}$ parasites $\mathrm{g}^{-1}$ wwt in all groups except those fed cultured parasites (Fig. 2A). All oysters receiving cultured parasites via feeding survived the experiment and the final mean parasite burden was only $10^{3}$ parasites $\mathrm{g}^{-1}$ wwt. Parasite burdens in oysters dosed with cultured parasites tended to increase as barriers to infections were breached, except that intubation and shell cavity were in reverse order from that expected (see Table 1), and a 1-way ANOVA indicated a significant difference among dosing methods ( $\mathrm{p}=0.0001)$. Bonferroni mean separations indicated that burdens from the following methods were not statistically different: feeding and intubation; intubation and shell-cavity injection; shellcavity injection and adductor muscle injection. The same statistical comparison cannot be made with oysters dosed with wild-type parasites because of low survivorship in some groups. The oyster that died after being intubated with cultured parasites had a $P$. marinus burden of only $10^{1.6}$ parasites gwwt ${ }^{-1}$ and the means for those dying during the early phase in the other treatments were also low $\left(\sim 10^{3}\right.$ parasites $\mathrm{g}^{-1}$ wwt.) It is likely that these oysters died from trauma compounded by $P$. marinus infection (see Ford et al. 2002). Mean burdens of oysters dying during the late phase were similar in all groups ( $10^{5.8}$ to $\left.10^{7.2} \mathrm{~g}^{-1} \mathrm{wwt}\right)$. Control oysters had light parasite burdens (mean = $10^{2.5}$ parasites $\mathrm{g}^{-1} \mathrm{wwt}$ ) at the end of the trial, but these were 1 or more orders of magnitude lower than those of experimental groups except those fed parasites.

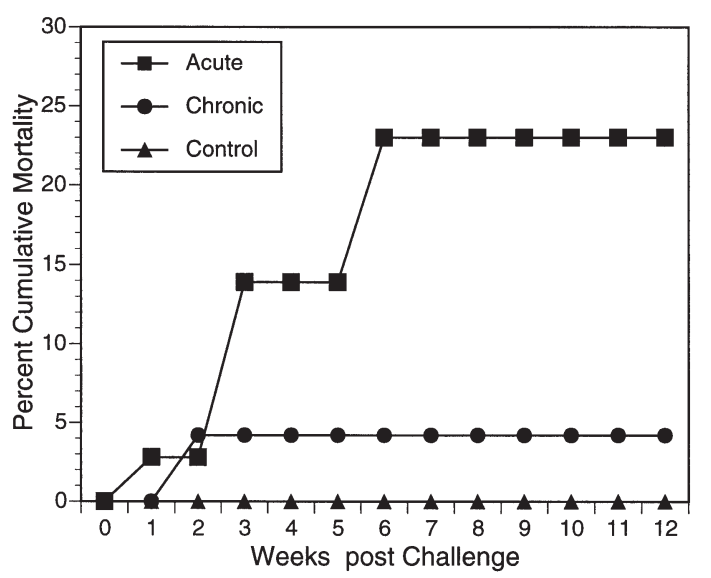

Fig. 3. Crassostrea virginica. Cumulative mortality of susceptible eastern oysters challenged by feeding with in vitrocultured Perkinsus marinus mixed with an algal diet. Acute challenge was by feeding $2.4 \times 10^{8}$ parasites in 1 dose at the start of the trial; chronic challenge was by feeding the same quantity of parasites in 24 separate doses of $10^{7}$ parasites 3 times a week for $8 \mathrm{wk}$. Starting $\mathrm{N}=36$ for each treatment group and 18 for controls 


\section{Virulence index}

Calculation of the VI enabled a more thorough statistical analysis because it included both mortality and parasite burdens, which effectively recovered samples that were lost when using either measure alone. A 2-way ANOVA indicated that dosing method, as well as parasite type, had a highly significant effect on the VI ( $p=0.0001)$. The ranking of VI according to treatment was the same for both wild-type and cultured parasites: adductor muscle $>$ shell cavity $>$ intubation $>$ feeding (Fig. 2B) and a Bonferroni post-hoc test confirmed that the VI of oysters injected via the adductor muscle was significantly higher than those dosed by feeding, but statistically similar to those dosed via shell-cavity injection and intubation.

\section{Expt II. Acute vs chronic feeding of parasites and their subsequent distribution in oyster tissues}

\section{Mortality}

Cumulative mortality of oysters fed the entire dose of Perkinsus marinus at the start of the trial was $23 \%$ compared to $4 \%$ for those dosed chronically for $8 \mathrm{wk}$ (Fig. 3). All deaths occurred between Weeks 1 and 6, and only 1 dead oyster had a parasite burden greater than $10^{2.5}$ parasites $\mathrm{g}^{-1}$ wwt. There were no statistical differences in mortality associated with feeding regime, probably because oysters were continuously removed for diagnosis, resulting in a very small sample size at the end of the experiment. No control oysters died.

\section{Parasite burdens}

Infection prevalence was $100 \%$ in live and dead oysters at all sampling dates. Mean parasite burdens were very low for both treatments, never exceeding $10^{2}$ parasites $g^{-1}$ wwt during the entire experiment (Fig. 4). The Day-3 parasite burdens for the acute treatment were 1 order of magnitude higher than those of the chronic treatment group. At that time, the former had received 24 times the dose administered to the latter. The burdens were reversed by Day 14, with the chronic-exposure oysters having higher mean parasite loads until the end of the experiment. A 2-way ANOVA, however, showed no significant effects of time, dosing method, or their interaction on parasite burdens. Burdens in experimental oysters were rarely more than 1 order of magnitude higher than those in control oysters (Fig. 4). There were no significant differences in tissue weight associated with treatment or

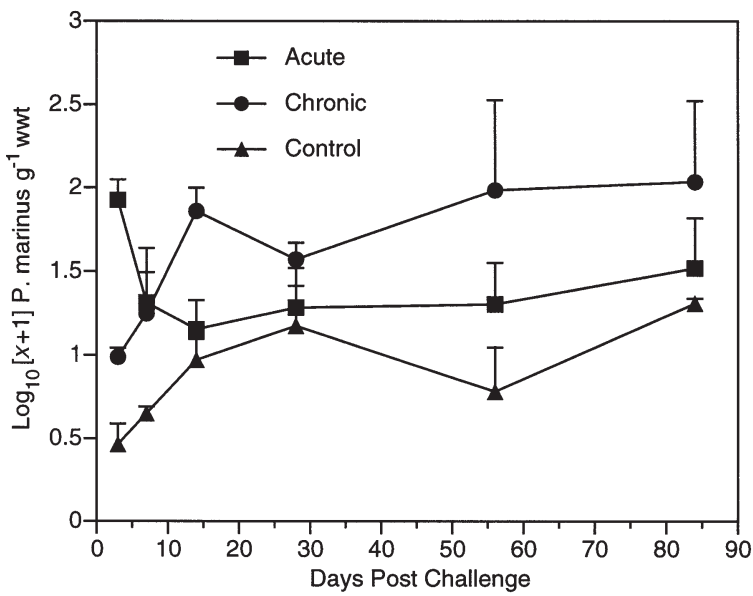

Fig. 4. Perkinsus marinus. Time-course of parasite burdens (mean \pm SEM) in whole susceptible eastern oysters, Crassostrea virginica, challenged with acute or chronic feeding of in vitro-cultured parasites in an algal diet. $\mathrm{N}=6$ per sampling period for each treatment group and 3 for controls

over time during the experiment, indicating that differences in weight-specific parasite loads were not caused by changes in weight.

\section{Distribution of parasites among host tissues}

The pattern of change in parasite loads in the various tissue compartments (Fig. 5) resembled that for the whole-body parasite burdens. In oysters treated by acute dosing, burdens in all tissues except the hemolymph were highest on Day 3, declined over the first $2 \mathrm{wk}$, then stabilized (Fig. 5A). Burdens in the hemolymph remained very low and stable throughout the study. In oysters treated by chronic dosing, burdens in the mantle, gill, and digestive gland increased over the first $2 \mathrm{wk}$, but followed no particular pattern thereafter (Fig. 5B). Two-way ANOVAs performed for each tissue showed no effect of either sampling time or dosing method, a marginally significant interaction between these factors for the mantle $(\mathrm{p}=0.046)$, marginally insignificant for the gill $(\mathrm{p}=$ 0.055), and a significant interaction for the remainder $(p=0.015)$. Throughout the experiment, mean burdens in mantle, gill, and digestive gland were consistently higher than those for the hemolymph and the remaining viscera. Parasite densities in one tissue compartment were rarely correlated with those in another (only 14 of 120 possible associations were statistically significant) and most of the significant correlations occurred during the first $2 \mathrm{wk}$ of the experiment when the change in parasite burdens was most rapid. 


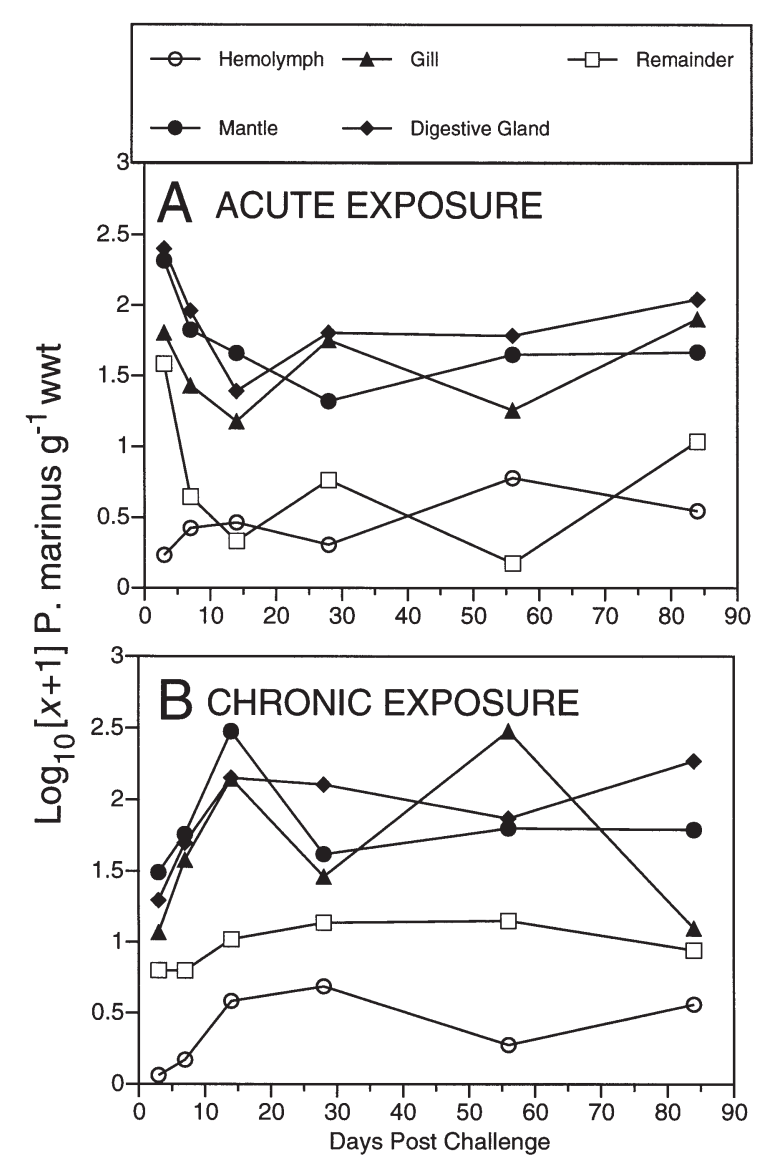

Fig. 5. Perkinsus marinus. Time-course of mean parasite burdens in tissue compartments of susceptible eastern oysters, Crassostrea virginica, challenged with (A) acute or (B) chronic feeding of in vitro-cultured parasites in an algal diet. $\mathrm{N}=6$ per sampling period for each treatment group. Error bars omitted for sake of clarity

\section{Expt III. Parasite distribution in oyster tissues after shell-cavity injection}

All dissected tissue compartments contained parasites on both Day 3 and Day 87 samplings and densities were 2 to 3 orders of magnitude higher than those in oysters dosed by feeding in Expt II (cf. Figs. 5 \& 6). At both times, and regardless of culture phase injected, the shell cavity fluid had the lowest parasite densities, followed by the hemolymph, and then by the digestive gland and remaining tissues (Fig. 6). Two-way ANOVAs performed separately for each body compartment indicated that culture phase always had a significant $(p<0.007)$ effect on parasite burden (Ford et al. 2002), but that the difference between Days 3 and 87 was significant $(p=0.030)$ only in the shell cavity fluid, where parasite densities increased over time (Fig. 6).
Despite the lack of change in the mean parasite burdens over time, differences were observed by other measures. Three days after inoculation, parasite burdens in the shell cavity were poorly associated with burdens in the tissues, but by Day 87, the slopes of all relationships had increased dramatically and strong correlations had developed (Fig. 7, Table 4). Similarly, on Day 3, parasite burdens in a particular compartment were generally unrelated to those in other compartments. Only 5 of 18 possible comparisons were significant, with correlation coefficients between 0.591 and 0.724 . On Day 87, all possible correlations were significant ( $p=0.0001$ to 0.0247 ) with correlation coefficients from 0.553 to 0.970 .

There was also a marked change between Days 3 and 87 in the frequency distribution of parasite burdens of individual oysters, and the change was

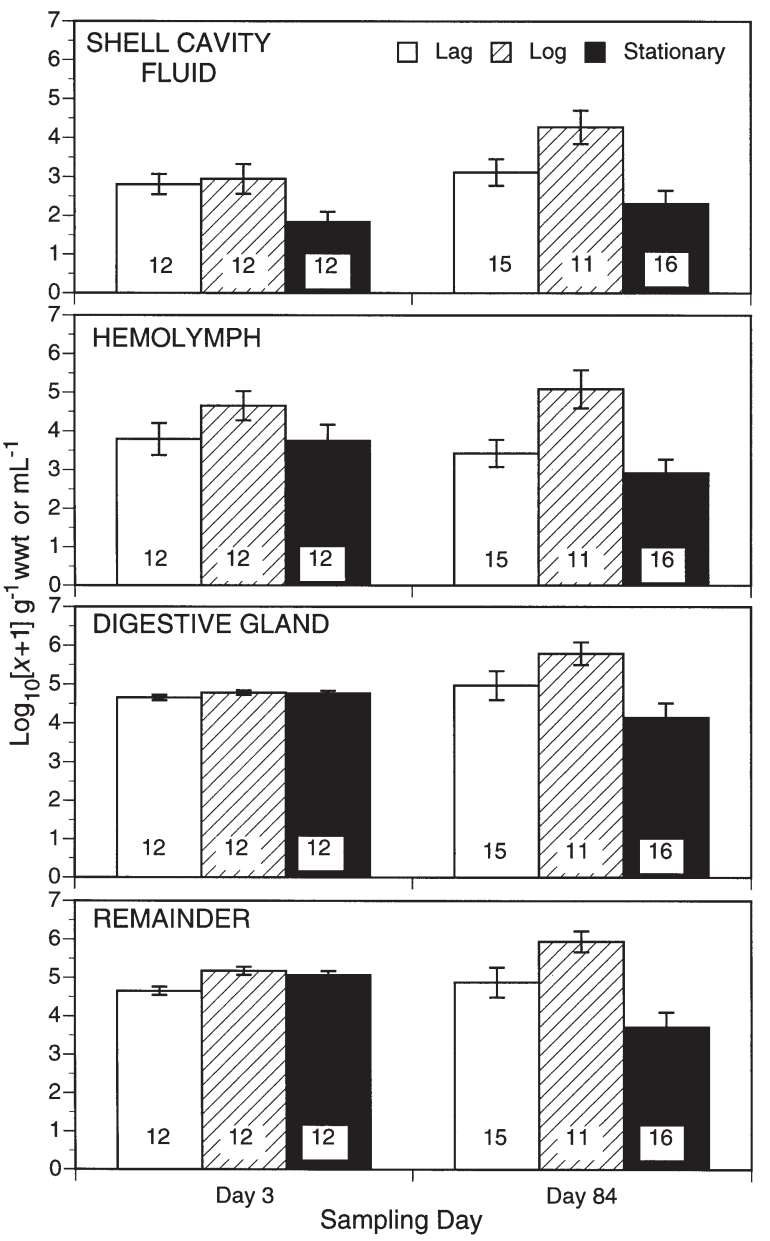

Fig. 6. Perkinsus marinus. Mean $( \pm$ SEM) parasite burdens in tissue and shell-cavity compartments of susceptible eastern oysters, Crassostrea virginica, 3 and $87 \mathrm{~d}$ after challenge by shell-cavity injection with $10^{6}$ parasites $\mathrm{g}^{-1}$ wwt of 1 of 3 phases (lag, log, and stationary) of in vitro-cultured parasites. Number of oysters in each group is shown at bottom of bars 


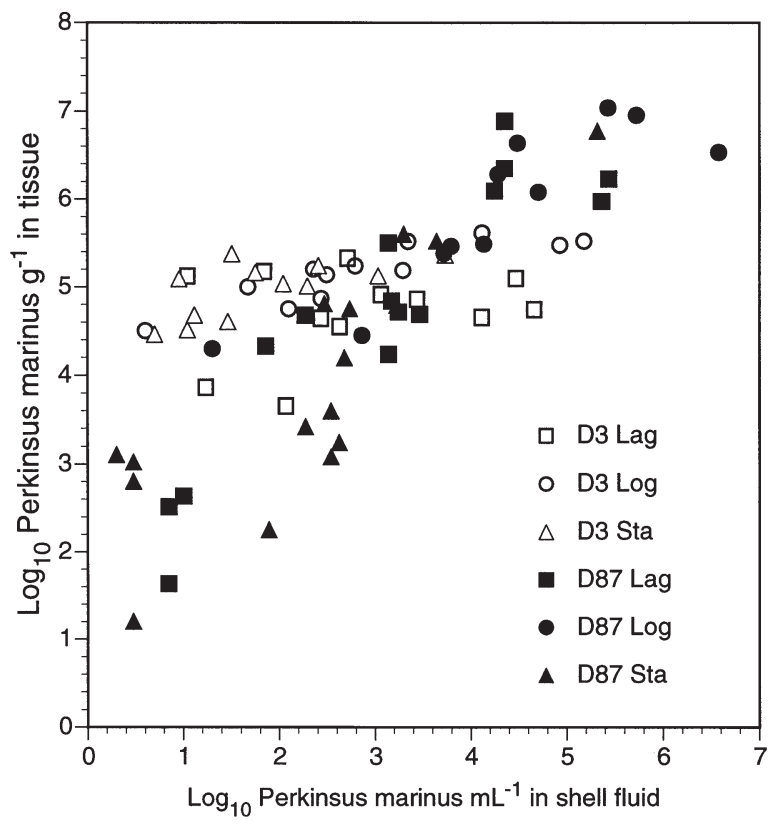

Fig. 7. Perkinsus marinus. Scattergram showing relationship of parasite burdens in the shell-cavity fluid to those in the tissues of susceptible eastern oysters, Crassostrea virginica, 3 and $87 \mathrm{~d}$ after challenge with $10^{6}$ parasites $\mathrm{g}^{-1}$ wwt of 1 of 3 phases (lag, log, and stationary) of in vitro-cultured parasites. Regression lines not provided for sake of clarity; however, regression statistics are given in Table 4

strongly associated with the culture phase of injected Perkinsus marinus (Fig. 8). On Day 3, the range was from approximately $10^{3.5}$ to $10^{5.5}$ parasites $\mathrm{g}^{-1}$ wwt and was similar for all culture phases; $12 \mathrm{wk}$ after the challenge, oysters injected with lag- and stationary-phase parasites displayed a wide range of $P$. marinus burdens ( $10^{1.0}$ to $10^{6.5}$ parasites $\left.\mathrm{g}^{-1} \mathrm{wwt}\right)$. In contrast, oysters injected with log-phase parasites were grouped at the upper end of the range ( $10^{4.0}$ to $10^{6.7}$ parasites $\left.\mathrm{g}^{-1} \mathrm{wwt}\right)$.

Between Days 3 and 87, the weight of the digestive gland and remaining soft tissues declined $(p=0.0001)$

Table 4. Perkinsus marinus. Correlation and regression statistics for comparisons between tissue parasite burdens and numbers of parasites in shell-cavity fluids of Crassostrea virginica on Days 3 and 87 following shell-cavity injection

\begin{tabular}{|lcccc|}
\hline \multirow{2}{*}{ Culture phase } & \multicolumn{2}{c}{ Correlation } & \multicolumn{2}{c|}{ Regression } \\
& $\mathrm{r}^{2}$ & $\mathrm{p}$ & Slope & $\mathrm{p}$ \\
\hline Day 3 & & & & \\
Lag & 0.066 & 0.4307 & 0.112 & 0.4667 \\
Log & 0.760 & 0.0001 & 0.243 & 0.001 \\
Stationary & 0.437 & 0.0171 & 0.226 & 0.187 \\
Day 87 & & & & \\
Lag & 0.830 & 0.0001 & 0.922 & 0.001 \\
Log & 0.789 & 0.0001 & 0.551 & 0.001 \\
Stationary & 0.712 & 0.0001 & 0.867 & 0.001 \\
& & & & \\
\hline
\end{tabular}

by 25 to $30 \%$ and the volume of hemolymph by $50 \%$ $(p=0.0001)$. In contrast, the volume of shell cavity fluid increased by $140 \%(p=0.0001)$. The changes in the fluid volumes exaggerated the change in parasite numbers in these compartments. Thus, the total burden in the shell cavity fluid increased, over time, from a mean of $10^{3.0}$ to a mean of $10^{4.0}$ parasites oyster ${ }^{-1}(\mathrm{p}=$ $0.0040)$ whereas those in the hemolymph declined from $10^{4.7}$ to $10^{4.0}$ parasites oyster ${ }^{-1}(p=0.0480)$.

\section{Expt IV. Metabolic condition of host}

\section{Mortality}

All groups experienced mortality during the first 2 wk after challenge; however, it was considerably greater in the 2 wk-holding group than in the $6 \mathrm{wk}$

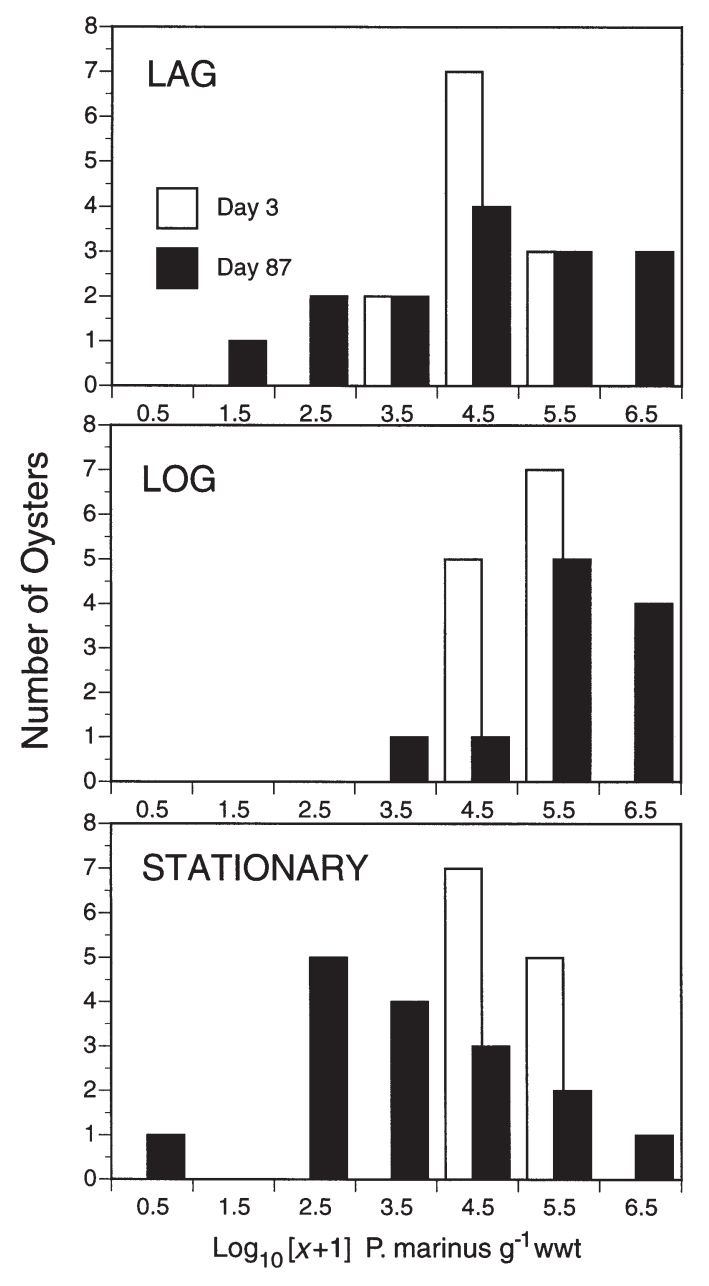

Fig. 8. Perkinsus marinus. Frequency distributions of total parasite burdens in susceptible eastern oysters, Crassostrea virginica, 3 and $87 \mathrm{~d}$ after challenge by shell-cavity injection with $10^{6}$ parasites $\mathrm{g}^{-1}$ wwt of 1 of 3 phases (lag, log, and stationary) of in vitro-cultured parasites 


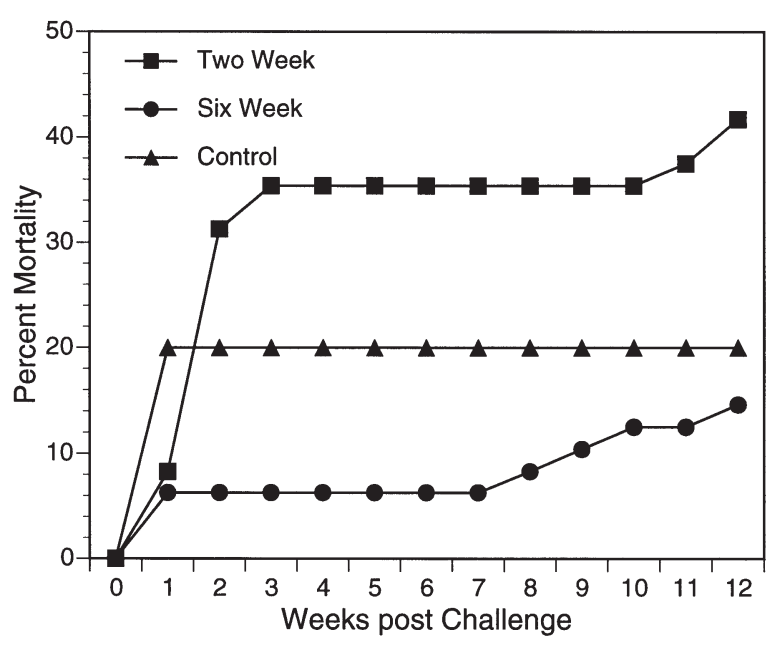

Fig. 9. Crassostrea virginica. Cumulative mortality of susceptible eastern oysters challenged by shell-cavity injection with $10^{6}$ parasites $\mathrm{g}^{-1}$ wwt of in vitro-cultured Perkinsus marinus after being held for 2 or $6 \mathrm{wk}$ at $10^{\circ} \mathrm{C}$ and $25 \mathrm{ppt}$

group or in the controls (Fig. 9). A few additional deaths occurred in the 2 experimental groups toward the end of the experiment. The final mortality in the 2 wk treatment was significantly higher than in the 6 wk treatment ( 42 vs $15 \% ; p=0.0014$ ). The 2 wk oysters had ripe gonads when the experiment started and spawned soon after being placed at the $28^{\circ} \mathrm{C}$ experimental holding temperature. This event fouled the water and, combined with temporary failure of an air compressor used to aerate the holding tanks, probably aggravated the mortalities. The 6 wk oysters spawned to a lesser extent, as they possibly had resorbed gametes during the prechallenge period at $10^{\circ} \mathrm{C}$.

\section{Parasite burdens}

Not only did the 2 wk group have greater mortality than the 6 wk group, but the survivors had significantly higher $(\mathrm{p}=0.0161)$ parasite burdens (Table 5). In the 2 wk group, 15 of 20 dead oysters had parasite burdens greater than $10^{5}$ parasites $\mathrm{g}^{-1} \mathrm{wwt}$, whereas only 3 of 6 in the 6 wk group had such heavy infections, and 2 had fewer than 10 parasites $\mathrm{g}^{-1}$ wwt. Nevertheless, there were no statistical differences in burdens of the dead oysters.

A few parasites (<10 per oyster) were found in control oysters, but the single control oyster that died had no detectable Perkinsus marinus. There was no significant effect of treatment on the meat weights of oysters, indicating that differences in weight-specific parasite loads were not caused by changes in weight.
Virulence index

The patterns observed above were strengthened when combined into a VI. The VI of the $2 \mathrm{wk}$ holding group was twice that of the 6 wk group ( $p=0.0004$; Table 5).

\section{DISCUSSION}

Virulence is a measure of the inherent disease-causing ability of an infectious agent. Rates of pathogen proliferation in the host and rates of host mortality are typically used to assess virulence, but such measurements can be affected by the parasite's environment and lead to mistaken conclusions about levels of inherent virulence. We distinguish between inherent virulence (see Ford et al. 2002) and 'apparent' or 'observed' virulence, the latter being that which is typically measured and reported as virulence. Our results showed that the method of dosing oysters with Perkinsus marinus had a major impact on the apparent virulence of the parasite by affecting the speed with which infections became established in host tissues and became lethal. Our results also showed that the apparent virulence of $P$. marinus can be altered by factors associated with the condition of experimental oysters. In nature, apparent virulence is also associated with the pathogen's environment. Thus, a given parasite may appear virulent in one host because that host is susceptible to, and mounts a poor defense against, the parasite, whereas the same parasite appears avirulent in another host that has good defenses or is insusceptible (e.g. Burreson et al. 2000). The external environment may also affect apparent virulence. For instance, a marine parasite may be highly virulent in waters with high salt content, but less so in estuarine salinities (Ford \& Tripp 1996).

Because of the hierarchy in barriers to infection (see Table 1), we hypothesized that the rate at which infections would develop and become lethal following Perkinsus marinus challenge by various delivery meth-

Table 5. Perkinsus marinus. Mean (SEM) parasite burdens $\left(\log _{10}[x+1] g^{-1}\right.$ wwt) in dead and surviving oysters, Crassostrea virginica, and mean (SEM) virulence index (VI) for oysters injected with $P$. marinus after 2 and 6 wk prechallenge holding periods

\begin{tabular}{|rrccccc|}
\hline \multirow{2}{*}{ Period } & \multicolumn{4}{c}{ Parasite burdens } & \multicolumn{2}{c|}{ Virulence index } \\
& \multicolumn{2}{c}{ Dead } & \multicolumn{2}{c}{ Survivors } \\
& $\mathrm{N}$ & Burden & $\mathrm{N}$ & Burden & N & VI \\
\hline $2 \mathrm{wk}$ & 20 & $6.29(0.280)$ & 28 & $4.27(0.244)$ & 48 & $4.73(0.406)$ \\
$6 \mathrm{wk}$ & 6 & $4.65(1.163)$ & 42 & $3.10(0.197)$ & 48 & $2.29(0.171)$ \\
& & & & & & \\
\hline
\end{tabular}


ods would be adductor muscle injection $>$ intubation $>$ shell-cavity injection $>$ feeding. This was true, statistically, for the adductor muscle injection vs feeding method comparison, but not for the other comparisons. The statistical similarity between results for shellcavity and adductor-muscle injection confirms an earlier study (Bushek et al. 1997), indicating that the former is a reasonable substitute for the more invasive direct tissue injection. Although we cannot discount the possibility that minor tissue damage during the shell notching and shell-cavity-injection procedures may have permitted the entry of parasites directly into the tissues, we made every effort to minimize this possibility by making very small holes in the shell and by using smoothed, blunt-tipped needles, so that the number of parasites potentially introduced this way would have been very small relative to the quantity introduced directly into the adductor muscle or the gut.

Dosing-method studies not only provide information for design of experiments, they also indicate likely routes of entry of the parasite in nature. Although not statistically significant, the virulence index rank of both wild-type and cultured parasites introduced via shell-cavity injection and by intubation was the reverse of that expected, i.e. shell-cavity-injected parasites appeared to be equally, if not more virulent. The ability of shell-cavity-injected parasites to infect and replicate at a rate at least equal to that of intubated parasites suggests that the gut epithelium may not be the primary portal of entry as originally suggested by Mackin (1951). Instead, they support the findings of Perkins (1976) and Dungan et al. (1996) that the external epithelia of the gill, mantle, and labial palps are equally, if not more, important. Many intubated parasites may not have survived the digestive process in the stomach, as was hypothesized to explain the very low apparent virulence of the prokaryotic fish pathogen Piscirickettsia salmonis delivered via intubation into the stomach compared to that delivered by skin, gill patches, or by direct injection (Smith et al. 1999). When we provided oysters with Perkinsus marinus in their food or via shell-cavity injection, the outcome was similar: within $3 \mathrm{~d}$ of dosing, parasite densities were the same in the gill and mantle as in the digestive gland. Likely routes of entry were documented by Dungan et al. (1996) by using a fluorescentlabeled anti- $P$. marinus antibody: $21 \mathrm{~d}$ after experimental challenge, they found $P$. marinus in the epithelium and connective tissues of the mantle, palps, and gill, and in the connective tissues around the gut, but not in the epithelium of this organ. It is relevant that all the reports showing the digestive gland to have the highest $P$. marinus densities come from studies of wild oysters in which infections were well-established rather than newly acquired (Choi et al. 1989, Mackin
1951, Oliver et al. 1998). As postulated by Dungan et al. (1996), P. marinus may become concentrated in the digestive gland and, for some reason, this may increase the parasite's fitness. It may be that adjacent parasites release metabolites that stimulate proliferation, as hypothesized by Gauthier \& Vasta (1995). Bushek et al. (2000) found that holding individual $P$. marinus in proximity to actively proliferating cultures facilitated the establishment of clones.

With the exception of direct injection into the hemolymph, all dosing methods tested required parasites to traverse an epithelium. How Perkinsus marinus crosses the epithelium is not fully understood. Based on the observation that $P$. marinus is often found inside phagocytes (Mackin 1951), Mackin \& Boswell (1955) suggested that the parasites are transported by hemocytes across an epithelium into the circulatory system. Alvarez et al. (1992) subsequently demonstrated the feasibility of entry via the digestive epithelium by intubating oysters with fluorescent beads that they subsequently found, in histological sections, distributed in connective tissues. Perhaps not surprisingly, given the likelihood of leakage of beads into the gill cavity and the abundance of hemocytes in this compartment (Paillard et al. 1996), beads were also found in the mantle and gill tissues as early as $2 \mathrm{~h}$ post-intubation (Alvarez et al. 1992). Further, a recent study showed that beads placed directly into the shell cavity of oysters were quickly ingested and carried into the mantle and gills (Allam \& Ford 2002).

Although the VI of wild-type Perkinsus marinus was much greater than that of cultured parasites, the ranking of dosing methods was the same for both parasite types. The significance of this finding is that the relative importance of various invasion routes is independent of parasite type and that the higher virulence of the wild-type $P$. marinus is not because they are more capable of taking advantage of one particular route or bypassing a certain barrier (e.g. better at attaching to invasion sites on the gill rather than surviving extracellular or intracellular digestion mechanisms). The lower virulence of the cultured parasites is likely to be a more universal mechanism, such as lower viability outside the culture medium (Ford et al. 2002).

The role of the shell cavity fluid, the external epithelia, and the hemocytes in the dynamics of Perkinsus marinus infections is further illustrated by the tissue distribution of experimentally administered parasites. A curious aspect of the comparison between chronic versus acute feeding was that the parasite loads stabilized over time, and at approximately the same levels, in both treatments (Fig. 4). The decrease in parasite densities over the first $2 \mathrm{wk}$ in oysters fed the entire dose at the beginning of the trial indicates that many parasites were actively eliminated by the oysters or 
simply did not survive in their new environment. After the initial $2 \mathrm{wk}$, no further decline in $P$. marinus burdens was observed. Parasite burdens in oysters given smaller, repeated doses built up over the first couple of weeks, then stabilized at approximately the same level as those in the acute dosing, even though the former were still being dosed on a regular basis. The question arises as to why burdens in oysters dosed only once did not continue to decline over time and why those in the continuously fed individuals did not continue to increase. The patterns, particularly that in the chronically dosed oysters, suggest a dynamic equilibrium between invasion and elimination. Elimination could be achieved by intracellular digestion of $P$. marinus (La Peyre et al. 1995, Bushek et al. 1997) or via transportation of live parasites across external epithelia inside hemocytes (Mackin 1951, Tripp 1960, Ford \& Tripp 1996). In fact, we found a significant increase of P. marinus in the shell cavity fluid $87 \mathrm{~d}$ after injection into that compartment, indicating that parasites had accumulated there, either via elimination or replication. Their enlargement in Ray's fluid thioglycollate medium (RFTM) indicated that they were viable (Ray 1954) and a likely source for re-infection of the experimental oysters. It should be noted that the persistence of large numbers of $P$. marinus in the shell-cavity fluid may have been partly an artifact of the small water volume in which the oysters were maintained, which probably enhanced retention of parasites. In their natural environment, it is possible that the cavity would be better flushed and re-infection less likely. Nevertheless, large numbers of hemocytes are retained in the shell cavities of oysters and clams collected in the wild, suggesting that parasites could also persist in shell cavities (Paillard et al. 1996, Allam \& Paillard 1998). In any case, it is likely that parasites shed across external epithelia can either re-infect the same oyster or be dispersed into the water, like those discharged in the feces (Bushek et al. 1997, 2002 [this issue], Scanlon 1997), and become infective to other oysters.

The observation that parasite densities stabilized, rather than increased, during the chronic dosing experiment is more difficult to explain. Either the parasites became less infective over time, or something about the host changed as a result of the repeated dosing or the long-term holding. There is no evidence that the inherent virulence of Perkinsus marinus changes with time in culture (Ford et al. 2002), thus a change in the oyster is more likely. One hypothesis would be that the defense system of the oyster was mobilized during the first $2 \mathrm{wk}$ of the challenge and was thereafter able to deal more effectively with the repeated dosing. Perhaps the hemocytes migrating to sites of infection in the gill and mantle (Mackin 1951) enhanced the oyster's ability to eliminate parasites. A more likely expla- nation is that prolonged holding in small containers decreased the filtration activity of oysters so that they encountered fewer of the dosed parasites. This supposition is consistent with the finding of decreased numbers of $P$. marinus in the feces and pseudofeces over time in this experiment (Bushek et al. 2002).

On the surface, it seems surprising that the mean Perkinsus marinus burdens in most tissues of oysters dosed by shell-cavity injection did not change significantly between 3 and $87 \mathrm{~d}$ post-challenge. In fact, important changes did occur. For instance, parasites became more evenly distributed among tissues. Many parasites found at Day 3 were probably not in established infections, but simply adhering to surfaces and shed during the early post-challenge period (Bushek \& Allen 1996, Bushek et al. 2002). Those found at Day 87 represented well-established, systemic infections. Interestingly, cultured $P$. marinus delivered in the feeding experiment never became similarly well distributed, but remained as relatively superficial infections. Parasite burdens in control oysters, presumably infected by very small numbers of wild parasites, were similar to those in oysters chronically dosed with cultured parasites. The stabilization into an apparent dynamic equilibrium of $P$. marinus burdens in the latter may mimic the situation in nature when oysters are exposed to small numbers of wild parasites. This observation suggests that oysters can effectively control chronic small doses, keeping parasite burdens below the level detectable by standard diagnostic assays (Bushek et al. 1994). Such a condition would allow infected oysters to persist undiscovered and to serve as foci for epizootic outbreaks if conditions change (Ford 1996).

Use of mean parasite burdens can also be misleading in that it fails to describe their distribution among individual hosts. Frequency distributions were a much better indicator of change than were means during the post-shell-cavity challenge period (Fig. 8). They indicated that stationary- and lag-phase Perkinsus marinus were easier for oysters to control or eliminate than were log-phase parasites (see also Ford et al. 2002) and illustrated the wide range in these abilities among the experimental oysters. Interestingly, $10 \%$ of the oysters had a total parasite burden more than 2 times greater than the remaining $90 \%$. It is likely to be the parasites in this small percentage of heavily infected hosts that initiate epizootics (Ford et al. 1999).

In a companion study (Ford et al. 2002), we noted a possible effect of prolonged pre-challenge holding of experimental oysters on the development of Perkinsus marinus infections, an observation that we attributed to the metabolic state of the host. We attempted to test this hypothesis in the current study. In contrast to the first study, however, infections developed more rapidly 
in oysters held for just $2 \mathrm{wk}$ before challenge than in those held for $6 \mathrm{wk}$. Those oysters held only $2 \mathrm{wk}$ spawned shortly after they were injected. The release of gametes occurred over several days, and even though the water was changed as soon as gametes were observed, it is likely that the oxygen level decreased and the concentration of waste products increased, especially as this occurred at a time when there was also a temporary failure in the air supply to the buckets. This event was accompanied by mortality in both control and experimental oysters, suggesting that it was not associated with $P$. marinus. Nevertheless, parasite densities in both live and dead oysters were significantly higher in the 2 wk group than in the 6 wk group (which spawned to a lesser extent and did not experience the air-supply problem), indicating that $P$. marinus had actually proliferated to a greater degree in the former. Thus, it is likely that one or more of the putative stressors-spawning, fouled water, or low oxygen - had enhanced the ability of $P$. marinus to infect and proliferate in the $2 \mathrm{wk}$ group. The mechanism by which this may have occurred is unknown, but other studies found elevated $P$. marinus infections associated with low dissolved oxygen (Chu \& Hale 1994) and increased proliferation in culture at high $\mathrm{CO}_{2}$ concentrations (La Peyre \& Faisal 1996). Oysters accumulate $\mathrm{CO}_{2}$ in their tissues when exposed to hypoxia (Dwyer \& Burnett 1996). Thus, in our experiments, fouled water and the failed air supply may have lowered dissolved oxygen and inhibited gill ventilation over a period of several days. The result may have been an increase in $\mathrm{CO}_{2}$ within the tissues, thus improving the environment for $P$. marinus.

It is clear from this study that different dosing methods and host condition can alter estimates or measures of Perkinsus marinus virulence. This has important implications for experimental design and comparison of data from different studies. Investigators should carefully consider the purpose of a challenge experiment in order to select an appropriate dosing method.

Acknowledgements. We thank J. Gandy, K. Alcox, J. Oxley, I. Eleazar, T. Ferarra, D. Ianniello, L. Smith, C. Spruck, and R. Holley for assistance in maintenance of oysters and processing of samples; J. Heltshe for statistical consultation; and S. Benyi, R. Gobell and K. Rocha for critical review of the manuscript. This study was supported by the NOAA Oyster Disease Research Program under grants NA47FL0153 and NA57FL0042. This is publication No. 2001-18 from the Institute of Marine and Coastal Sciences at Rutgers, No. D-324054-01 of the NJ Agricultural Experiment Station, contribution number 1298 of the Baruch Institute for Marine Biology and Coastal Research at the University of South Carolina, and EPA Atlantic Ecology Division contribution number 00-091. Mention of trade names or commercial products does not constitute endorsement or recommendation for use by the US Environmental Protection Agency. Although the research described in this article has been funded in part by the US Environmental Protection Agency, it has not been subjected to Agency review. Therefore, it does not necessarily reflect the views of the Agency.

\section{LITERATURE CITED}

Abacus Concepts (1994) Survival tools for StatView. Abacus Concepts, Berkeley, CA

Allam B, Ford SE (2002) Transport of particles across epithelia from oyster mantle cavity: a model for Perkinsus marinus invasion. J Shellfish Res 21:371

Allam B, Paillard C (1998) Defense factors in clam extrapallial fluids. Dis Aquat Org 33:123-128

Alvarez MR, Friedl FE, Hudson CM, O'Neill RL (1992) Uptake and tissue distribution of abiotic particles from the alimentary tract of the American oyster: a simulation of intracellular parasitism. J Invertebr Pathol 59:290-294

Andrews JD (1961) Measurement of shell growth in oysters by weighing in water. Proc Natl Shellfish Assoc 52:1-11

Burreson EM, Stokes NA, Friedman CS (2000) Increased virulence in an introduced pathogen: Haplosporidium nelsoni (MSX) in the eastern oyster Crassostrea virginica. J Aquat Anim Health 12:1-8

Bushek D, Allen SK Jr (1996) Host-parasite interactions among broadly distributed populations of the eastern oyster Crassostrea virginica, and the protozoan Perkinsus marinus. Mar Ecol Prog Ser 139:127-141

Bushek D, Ford SE, Allen SK Jr (1994) Evaluation of methods using Ray's fluid thioglycollate medium for diagnosis of Perkinsus marinus infection in the eastern oyster, Crassostrea virginica. Annu Rev Fish Dis 4:201-217

Bushek D, Allen SK, Alcox KA, Gustafson R, Ford SE (1997) Response of Crassostrea virginica to in vitro cultured Perkinsus marinus: preliminary comparison of three inoculation methods. J Shellfish Res 16:479-485

Bushek D, Holley RA, Reece KS (2000) Use of micromanipulation and 'feeder' cultures to clone the protozoan oyster pathogen Perkinsus marinus. J Eukaryot Microbiol 47(2): 164-166

Bushek D, Ford SE, Chintala MM (2002) Comparison of in vitro cultured and wild-type Perkinsus marinus. III. Fecal elimination and its role in transmission. Dis Aquat Org 51: 217-225

Choi KS, Wilson EA, Lewis DH, Powell EN, Ray SM (1989) The energetic cost of Perkinsus marinus parasitism in oysters. Quantification of the thioglycollate method. J Shellfish Res 8:117-125

Chu FLE (1996) Laboratory investigations of susceptibility, infectivity, and transmission of Perkinsus marinus in oysters. J Shellfish Res 15:57-66

Chu FLE, Hale R (1994) Relationship between pollution and susceptibility to infectious disease in the eastern oyster, Crassostrea virginica. Mar Environ Res 38:243-256

Dungan CF, Roberson BS (1993) Flow cytometric quantification and analysis of Perkinsus marinus cells present in estuarine waters. NOAA NMFS Oyster Disease Research Program, Contr. No. NA16FL0406-01, Gloucester, MA

Dungan CF, Hamilton RM, Burreson EM, Ragone-Calvo LM (1996) Identification of Perkinsus marinus portals of entry of histochemical immunoassays of challenged oysters. J Shellfish Res 15:500

Dwyer JJ III, Burnett LE (1996) Acid-base status of the oyster Crassostrea virginica in response to air exposure and to infections by Perkinsus marinus. Biol Bull (Woods Hole) 190:139-147 
Fisher WS, Oliver LH (1996) A whole-oyster procedure for diagnosis of Perkinsus marinus disease using Ray's fluid thioglycollate culture medium. J Shellfish Res 15: 109-117

Fisher WS, Chintala MM, Moline MA (1989) Annual variation of estuarine and oceanic oyster Crassostrea virginica Gmelin hemocyte capacity. J Exp Mar Biol Ecol 127: 105-120

Fisher WS, Oliver LM, Edwards P (1996a) Hematologic and serologic variability of eastern oysters from Apalachicola Bay, Florida. J Shellfish Res 15:555-564

Fisher WS, Winstead JT, Oliver LM, Edmiston HL, Bailey GO (1996b) Physiologic variability of eastern oysters from Apalachicola Bay, Florida. J Shellfish Res 15:543-553

Ford SE (1996) Range extension by the oyster parasite Perkinsus marinus into the northeastern US: response to climate change? J Shellfish Res 15:45-56

Ford SE, Tripp MR (1996) Diseases and defense mechanisms. In: Newell RIE, Kennedy VS, Eble AF (eds) The eastern oyster Crassostrea virginica. Maryland Sea Grant College, College Park, MD, p 383-450

Ford SE, Schotthoefer A, Spruck C (1999) In vivo dynamics of the microparasite Perkinsus marinus during progression and regression of infections in eastern oysters. J Parasitol 85:273-282

Ford SE, Chintala MM, Bushek D (2002) Comparison of in vitro-cultured and wild-type Perkinsus marinus. I. Pathogen virulence. Dis Aquat Org 51:187-201

Gauthier JD, Vasta G (1993) Continuous in vitro culture of the eastern oyster parasite Perkinsus marinus. J Invertebr Pathol 62:321-323

Gauthier JD, Vasta G (1995) In vitro culture of the eastern oyster parasite Perkinsus marinus: optimization of the methodology. J Invertebr Pathol 66:156-168

Kleinschuster SJ, Swink SL (1993) A simple method for the in vitro culture of Perkinsus marinus. Nautilus 107:76-78

La Peyre JF, Faisal M (1996) Optimal culture conditions for the propagation of the oyster pathogen Perkinsus marinus (Apicomplexa) in protein deficient medium. Parasite 3: 147-153

La Peyre JF, Faisal M, Burreson EM (1993) In vitro propagation of the protozoan Perkinsus marinus, a pathogen of the eastern oyster, Crassostrea virginica. J Eukaryot Microbiol 40:304-310

La Peyre JF, Chu FLE, Vogelbein WK (1995) In vitro interaction of Perkinsus marinus with hemocytes of eastern and Pacific oysters. Dev Comp Immunol 19:291-304

Mackin JG (1951) Histopathology of infection of Crassostrea virginica (Gmelin) by Dermocystidium marinum Mackin, Owen, and Collier. Bull Mar Sci Gulf Carib 1:72-87

Mackin JG (1962) Oyster diseases caused by Dermocystidium

Editorial responsibility: Albert Sparks,

Seattle, Washington, USA marinum and other microorganisms in Louisiana. Pub Inst Mar Sci Univ Tex 7:132-229

Mackin JG, Boswell JL (1955) The life cycle and relationships of Dermocystidium marinum. Proc Natl Shellfish Assoc 46: $112-115$

Mackin JG, Ray SM, Boswell JL (1953) Texas A\&M Research Foundation Project 23. Texas A\&M University, College Station, TX (Tech Rep No. 10)

Newell RIE, Barber BJ (1988) A physiological approach to the study of bivalve molluscan diseases. In: Fisher WS (ed) Disease processes in marine bivalve molluscs, Vol 18. American Fisheries Society, Bethesda, MD, p 269-280

Oliver LM, Fisher WS (1995) Comparative form and function of oyster Crassostrea virginica hemocytes from Chesapeake Bay (Virginia) and Apalachicola Bay (Florida). Dis Aquat Org 22:217-225

Oliver LM, Fisher WS, Ford SE, Burreson EM, Calvo LM, Sutton EB, Gandy JA (1998) Perkinsus marinus tissue distribution and seasonal variation in oysters (Crassostrea virginica) from Florida, Virginia, and New York. Dis Aquat Org 34:51-61

Osterhout S (1999) Host-parasite relationships. In: Joklik WK, Willett HP, Amos DB, Wilfert CM (eds) Zinsser microbiology. Appleton and Lange, Norwalk, CT, p 387-392

Paillard C, Ashton-Alcox K, Ford SE (1996) Changes in bacterial densities and hemocyte parameters in oysters affected by juvenile oyster disease. Aquat Living Resour 9:145-158

Perkins FO (1976) Zoospores of the oyster pathogen, Dermocystidium marinum. I. Fine structure of the conoic and other sporozoan-like organelles. J Parasitol 62:959-974

Ray SM (1952) A culture technique for the diagnosis of infections with Dermocystidium marinum, Mackin, Owen and Collier, in oysters. Science 166:360-361

Ray SM (1954) Biological studies of Dermocystidium marinum, a fungus parasite of oysters. Rice Institute, Houston, TX

SAS Institute (1990) SAS Language: Reference, Version 6, 1st edn. SAS Institute, Cary, NC

Scanlon CH (1997) The potential for transmission of Perkinsus marinus by fecal matter from the eastern oyster, Crassostrea virginica. MS thesis, The College of William and Mary, Williamsburg, VA

Smith PA, Pizarro P, Ojeda P, Contreras J, Oyanedel S, Larenas J (1999) Routes of entry of Piscirickettsia salmonis in rainbow trout Oncorhynchus mykiss. Dis Aquat Org 37:165-172

Tanada Y, Fuxa JR (1987) The pathogen population. In: Fuxa JR, Tanada Y (eds) Epizootiology of insect diseases. WileyInterscience, New York, p 113-157

Tripp MR (1960) Mechanisms of removal of injected microorganisms from the American oyster, Crassostrea virginica (Gmelin). Biol Bull (Woods Hole) 119:273-282

Submitted: December 8, 2000; Accepted: February 12, 2002 Proofs received from author(s): August 27, 2002 